\title{
Towards the establishment of cash waqf microfinance fund for refugees
}

\author{
Omar Ahmad Kachkar \\ ISRA Consultancy, Kuala Lumpur, Malaysia
}

\section{Cash waqf microfinance}

Received 1 March 2017 Revised 18 March 2017 Accepted 20 March 2017

\begin{abstract}
Purpose - This paper aims to propose cash waqf (endowment) to develop a conceptual model that can be utilised to extend microfinance for refugees.

Design/methodology/approach - Qualitative method is used in this research. An extensive review of the literature has been conducted. Latest literature on refugees, microfinance has been critically examined beside the current cash waqf models.

Findings - Empirical studies have shown that many refugees are equipped with marketable skills and talents that can be utilised to improve their socio-economic situations. The proposed model - cash waqf refugee microfinance fund (CWRMF) - is structured to extend microfinance to potential refugee micro entrepreneurs. To address the lack of collateral, which is a requirement to gain any microfinance, CWRMF has been incorporated with a takaful unit (cooperation) by which refugees may guarantee each other. Additionally, the model has also been structured to address the challenge of sustainability of the institution that would provide microfinance. Hence, a reserve fund has also been integrated into the model.

Practical implications - CWRMF represents a potential model to be implemented by humanitarian nongovernmental organisations (NGOs) and aid agencies to support livelihood of refugees in particular for Muslim refugees. Positive outcome is expected from the implementation of this model. This is because of the various advantages of microfinance programs not only on refugees but also on concerned NGOs, host populations and donor parties. Additionally, this paper is a set of primarily thoughts aims to open the door wider for more researchers to explore the potential of cash waqf as one of the instruments to finance refugee microenterprises and business activities.
\end{abstract}

Originality/value - Recently cash waqf has been into several models for socio-economic development and poverty alleviation. This paper is proposing cash waqf as a source for a microfinance fund that can contribute in the improvement of socio-economic situations of millions of refugees around the world.

Keywords Refugee, Cash waqf, Microfinance

Paper type Research paper

\section{Introduction}

The current phenomenal increase in the number of displaced populations and refugees has not been witnessed since the Second World War (UNHCR, 2015). According to the UNHCR report (UNHCR, 2016), a new record of 65.3 million displaced, including 21.3 million refugees, was set at the end of 2015. The length of time that refugees are spending in exile before they manage to return home has also increased to an average of 26 years (UNHCR,

(c) Omar Ahmad Kachkar. Published in the ISRA International Journal of Islamic Finance. Published by Emerald Publishing Limited. This article is published under the Creative Commons Attribution (CC BY 4.0) licence. Anyone may reproduce, distribute, translate and create derivative works of this article (for both commercial \& non-commercial purposes), subject to full attribution to the original publication and authors. The full terms of this licence may be seen at http://creativecommons.org/ licenses/by/4.0/legalcode

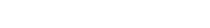

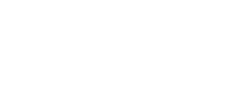


2016). With the scale of the refugee crisis, the current system of providing for the basic needs of refugees (e.g. food, drink, shelter and, at times, education and health care) is exhausting the resources of the United Nations (UN) agencies and humanitarian nongovernmental organisations (NGOs) and is deemed unsustainable in the long term. Even the solutions proposed by the United Nations High Commissioner for Refugees (UNHCR) in the form of repatriation, integration and resettlement have proven ineffective, insufficient and beyond the reach of the majority of refugees. What makes the situation even worse is the fact that over 85 per cent of refugees are hosted by poor developing countries which already have their own development and poverty challenges (UNHCR, 2016). There is thus increasing pressure on stakeholders to find sustainable solutions to the problems faced by refugees.

The economic engagement of refugees in income-generating activities, projects funded by microcredit and microfinance - what is commonly known as livelihood programmes has been long recognised as an effective means for improving refugees' livelihood and socioeconomic situations. This brief paper discusses how the charitable institution of waqf (endowment) can be used to develop a sustainable model to promote the economic engagement of refugees. It delves into the establishment of microfinance and start-up funds to promote entrepreneurship among refugees in refugee camps and urban areas. This model is particularly relevant to Muslim NGOs and might appeal to Muslim donors as it uses one of the well-known charitable institutions in Islam that has played a significant role throughout the history of Islamic civilisation in providing for the social, educational and economic welfare of Muslim communities.

\section{Cash waqf}

The concept of cash waqf can be traced back to as early as the second Hijri century (eighth century CE). Although the fatwa (legal ruling) of Imām Zufar (d. 158 H) is considered the most common reference on the permissibility of donating measurable or weighable properties including money as waqf (Cizakca, 2011), another account reveals that the issue of cash waqf was discussed among scholars even earlier. Imām al-Bukhāri reported that Imām Ibn Shihāb al-Zuhri (d. $124 \mathrm{H}$ ) was asked about the permissibility of a waqf in the form of 1,000 dinars held in perpetuity for trade with the profits being assigned to the poor and underprivileged (al-Bukhāri, 2002). Another account relating to cash waqf is found in the famous Māliki book 'al-Mudawwanah al-Kubrāh' which documented the fatwa of Imām Mālik (d. $179 \mathrm{H})$ that asserted the obligation of zakăh on 100 dinars offered as waqf to be given as loans to people (Imām Mālik, 1994).

The popularity of cash waqf has recently grown rapidly in Muslim societies. Many wealthy Muslims have been giving cash in the form of waqf to specific institutions; the funds are used for providing social services to the vulnerable groups of society (Cizakca, 1995).

Because of its distinct advantages in fund mobilisation and its liquid and flexible nature, cash waqf has recently been integrated into several models that have been developed for improving socio-economic development and poverty alleviation. The following are some examples of the use of cash waqf:

- for small- and medium-sized enterprises (Asmy, 2015; Lahsasna, 2010; Tohirin, 2010);

- for education (Aziz et al., 2013);

- for microfinance (Alpay and Haneef, 2015; Nadwi and Kroessin, 2013; Masyita, 2012; Ahmed, 2007; Zarka, 2007); 
- for economic development (Ibrahim et al., 2013);

- for use by financial institutions (Haji Mohammad, 2011; Abdel Mohsin, 2007);

Cash waqf microfinance

- for use by non-profit financial intermediaries (El-Gari, 2004);

- for poverty alleviation (Hassan and Ashraf, 2010);

- for microenterprises (Kahf, 2004; Ahmed, 2002); and

- for health care services (Ahmed, 2013).

\section{Proposed model}

A cash waqf refugee microfinance fund (CWRMF) is proposed to provide Islamic microfinance and microcredit facilities to refugee entrepreneurs who have the potential to run their own businesses and to support themselves. This model utilises the concept of cash waqf to raise funding required to provide these facilities.

As illustrated in Figure 1, two types of cash waqf are used, namely, temporary as well as perpetual cash waqf. The temporary cash waqf aims at targeting participants who would like to contribute funds to the model on a temporary basis. The funds are directed towards financing microfinance programmes for refugee micro-entrepreneurs. It is worth mentioning that it might be challenging for the management to keep finding temporary cash waqf donors to replace the old donors. However, this challenge can be overcome with proper marketing and promotion techniques. The second type is the perpetual cash waqf, comprising non-refundable donations. This type of cash waqf will be invested in relatively low-risk Sharī'ah-compliant investments, such as company shares or government șukük. The profits generated from the perpetual cash waqf investment will be channelled to the

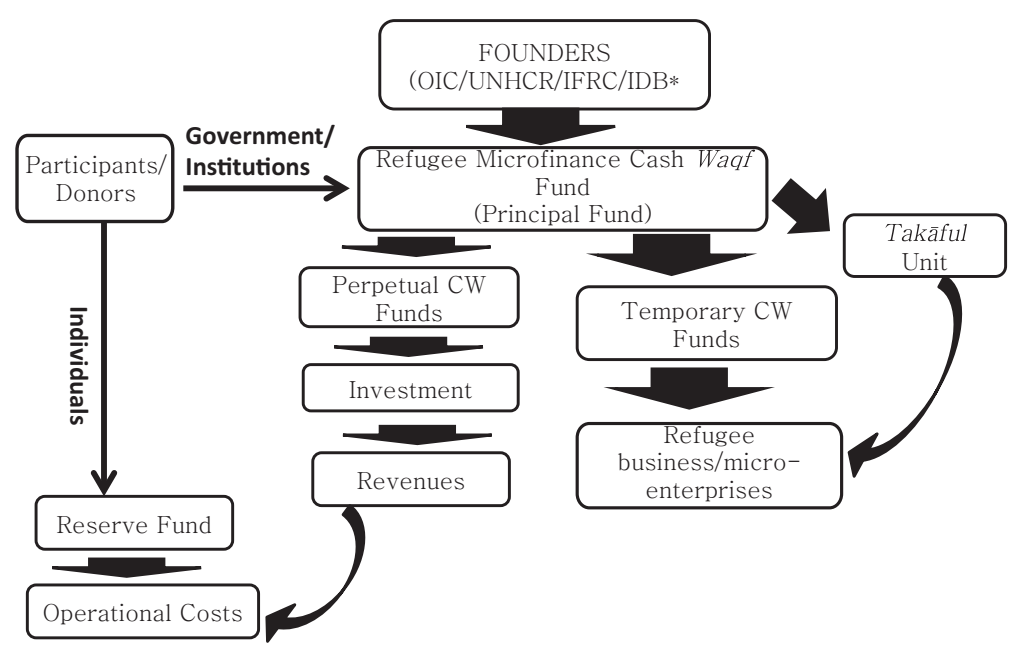

Notes: *OIC (Organisation of Islamic Cooperation); UNHCR (The United Nations High Commissioner for Refugees); IFRC (The International Federation of Red Cross and Red Crescent Societies); IDB (Islamic Development Bank)

Source: Author

Figure 1. Cash waqf refugee microfinance fund

(CWRMF) (conceptual model) 

of fundraising can also include the issuance of waqf certificates (sukukk) to participants or donors who can benefit from tax exemption as a form of incentive to encourage them to invest in the cash waqf fund.

As in the above self-explanatory model, the fund could be founded and monitored by well-established organisations such as the OIC, UNHCR, IFRC or IDB. Contributors and participants could also include governments, institutions, companies and banks. In this model, it is proposed that large contributions are dedicated to form the principal fund the CWRMF - whereas individual contributions can be directed to the reserve fund.

\section{Reserve fund}

The reserve fund has been incorporated in the model to ensure its sustainability. In addition to the profits generated by the perpetual cash waqf investment which are channelled to it, it will also include funds/charities collected from individual donors. These donations are expected to be accepted throughout the year and will be in small amounts. The reserve fund is expected to contribute to the operational expenses of the model in case the profits of the investment could not cover all the costs and expenses. Such expenses may include staff salaries, utility bills, office rents and others. The reserve fund would, in addition, keep the potential surplus amounts if there is any remaining from the investment revenues after settling the operational expenses.

\section{Takāful unit}

This unit would be integrated into the model to provide guarantees for refugee microenterprises. Each and every new participating refugee should join this unit before applying for any financial assistance. This unit is considered essential in the absence of any financial collateral and with the considerable ineffectiveness of social collateral in the refugee camp setting. Accordingly, new refugee entrepreneurs are required to obtain signed recommendations from older members of the takäful unit or the operating organisation. Additional functions of the takaful unit could include providing compensation for any default in the payment of refugees/participants for any reason of underperforming business or unexpected illness or death.

\section{Conclusion}

The refugee phenomenon has been widely perceived as a temporary problem; however, the statistics of the UNHCR confirm that nearly two-thirds of refugees are usually stuck in protracted situations, helpless and hopeless (UNHCR, 2016). Accordingly, temporary solutions have become ineffective and insufficient. This research note attempts to combine the advantages of microfinance and cash waqf to provide microfinancing facilities to refugees. The model uses two types of cash waqf, namely temporary and perpetual to be as accessible as possible to all potential participants. The model incorporates some risk management measures, in particular, the reserve fund to cover the operational expenses and the taka ful unit to address the issue of adverse selection and default risks. It is important to note that although the model is proposed for refugees, it can also be utilised to cater for microfinance programmes for all displaced and war-affected populations. Nonetheless, it is admitted that the model needs further refinement and that a number of issues need to be discussed such as the details of the modes of financing for refugees and the issuance of waqf certificates (șuku$k)$. 


\section{References}

Abdel Mohsin, M. (2007), "Financial cash-waqf institution", paper presented at the International Course on Islamic Financial Products: Principles and Applications, Organized by UiTM and IRTI/IDB, Kuala Lumpur.

Ahmed, H. (2002), "Financing microenterprises: an analytical study of Islamic microfinance institutions", Islamic Economic Studies, Vol. 9 No. 2, pp. 27-64.

Ahmed, H. (2007), "Waqf-based microfinance: realizing the social role of Islamic finance", paper presented at the International Seminar on Integrating Awqaf in the Islamic Financial Sector, Singapore, 6-7 March.

Ahmed, U. (2013), "Developing a waqf-based model for modern healthcare services in Uganda", $\mathrm{PhD}$ Thesis, International Islamic University Malaysia.

al-Bukhāri, M. (2002), Șah̄inh al-Bukhārī, Damascus, Dār Ibn Kathīr.

Alpay, S. and Haneef, M.A. (Eds) (2015), Integration of Waqf and Islamic Microfinance for Poverty Reduction: Case Studies of Malaysia, Indonesia and Bangladesh, SESRIC \& IIUM, Kuala Lumpur.

Asmy, M. (2015), "The financial and human capital development challenges of micro enterprises in Malaysia and the prospects for integrated cash waqf micro enterprise investment (ICWME-I) model", $\mathrm{PhD}$ thesis, International Islamic University Malaysia.

Aziz, M.R., Johari, F. and Yusof, M.A. (2013), “Cash waqf models for financing in education”, 5th Islamic Economic System Conference: Proceedings of a Conference, Universiti Sains Islam Malaysia, Kuala Lumpur, pp. 835-842.

Cizakca, M. (1995), “Cash waqfs of bursa, 1555-1823”, Journal of the Economic and Social History of the Orient, Vol. 38 No. 3, pp. 313-354.

Cizakca, M. (2011), "Waqf: its contribution and basic operational structure", Powerpoint presentation, INCEIF, available at: www.iqra.org.my/slide/Iqra\%20Waqf\%20101.pptx (accessed 21 March 2014).

El-Gari, M.A. (2004), "The qard hassan bank", paper presented at the International Seminar on Nonbank Financial Institutions: Islamic Alternatives, Kuala Lumpur, 1-3 March 2004.

Haji Mohammad, M.T.S. (2011). "Towards an Islamic social (waqf) bank", International Journal of Trade, Economics and Finance, Vol. 2 No. 5, pp. 381-386.

Hassan, M.K. and Ashraf, A. (2010), "An integrated poverty alleviation model combining zakat, awqaf and microfinance", paper presented at the Seventh International Conference - the Tawhidi Epistemology: Zakat and Waqf Economy, Bangi, 6-7 January.

Ibrahim, H., Amir, A. and Masron, T.A. (2013), "Cash waqf: an innovative instrument for economic development", International Review of Social Sciences and Humanities, Vol. 6 No. 1, pp. 1-7.

Imām Mālik, A. (1994), al-Mudawwanah al-kubrā, Dār al-Kutub al-Ñilmiyyah, Beirut.

Kahf, M. (2004), "Shari'ah and historical aspects of zakah and awqaf", Background paper prepared for Islamic Research and Training Institute, Islamic Development Bank.

Lahsasna, A. (2010), "The role of cash-waqf in financing micro and medium-sized enterprises", paper presented at the Seventh International Conference on the Tawhidi Epistemology: Zakat and Waqf Economy, Bangi, 6-7 January.

Masyita, D. (2012), "Sustainable Islamic microfinance institutions in Indonesia: an exploration of demand \& supply factors and the role of waqf", $\mathrm{PhD}$ thesis, Durham University, available at: http://etheses.dur.ac.uk/5942/1/Dian_Masyita-PhD_Thesis-2012.pdf?DDD35+ (accessed 19 February 2017).

Nadwi, M.A. and Kroessin, M. (2013), "Cash waqf: exploring concepts, jurisprudential boundaries and applicability to contemporary Islamic microfinance", Islamic Relief Worldwide Working Paper Series no. 2013-0x, Birmingham. 
Tohirin, A. (2010), "The cash waqf for empowering the small businesses", paper presented the Seventh International Conference on the Tawhidi Epistemology: Zakat and Waqf Economy, Bangi, 6-7 January.

UNHCR (2015), UNHCR Global Trends: Forced Displacement in 2014, Geneva, available at: http:// unhcr.org/2014trends/ (accessed 19 February 2017).

UNHCR (2016), UNHCR Global Trends: Forced Displacement in 2015, Geneva, available at: www. unhcr.org/statistics/unhcrstats/576408cd7/unhcr-global-trends-2015.html (accessed 19 February 2017).

Zarka, M.A. (2007), "Leveraging philanthropy: monetary waqf for micro finance", paper presented at the Symposium towards an Islamic Micro-Finance, Harvard Law School, Massachusetts, 14 April.

\begin{abstract}
About the author
Omar Ahmad Kachkar, PhD, is a Manager at ISRA Consultancy, the International Shari'ah Research Academy for Islamic Finance, Kuala Lumpur, Malaysia. He holds a $\mathrm{PhD}$ degree from the International Islamic University Malaysia (IIUM) and a Masters from Loughborough University, UK. His areas of interest include Sharīah advisory, Sharīah Standards, cash waqf and microfinance. Omar Ahmad Kachkar can be contacted at: omar@isra.my
\end{abstract}

For instructions on how to order reprints of this article, please visit our website: www.emeraldgrouppublishing.com/licensing/reprints.htm Or contact us for further details: permissions@emeraldinsight.com 